\title{
Response of Nigerian Construction Industry to Economic Growth
}

\author{
Ojo, O. J. ${ }^{\cdot 1}$, Yusuf, B. A. ${ }^{2}$, Anjonrin-Ohu A. ${ }^{3}$ \\ ${ }^{*}$ Department of Project Management Technology, Federal University of Technology, Akure, Ondo State, \\ Nigeria \\ ${ }^{2}$ Department of Building Technology, The Polytechnic, Ibadan, Oyo State, Nigeria \\ ${ }^{3}$ Department of Quantity Surveying, The Polytechnic, Ibadan, Oyo State, Nigeria
}

\begin{abstract}
The study assessed response of Nigerian Construction Industry to economic growth of Nigeria. The research was conducted using secondary data. The secondary data used was the National Account Dataset from 1981 to 2018 as 2010 constant price year. This was gotten from the Central Bank of Nigeria (CBN) publication reports. The response was evaluated through Impact propensity (IP), Finite Distributed Lag (FDL) and the Long Run Propensity (LRP). These parameters were calculated from the time series regression analysis using ordinary Least Square Method of estimation. The results show that the impact propensity of economic growth on construction is weak with correlation coefficient of -0.012. Delayed impact of economic growth on construction was observed with finite distributed lag of two year cycle. Maximum correlation coefficient of 1.265 with the economics of the preceding year $(t-1)$ was observed. Long run propensity of 1.333 establishes a high growth propensity for construction industry given a one percent permanent GDP growth. Therefore, the study concluded that a consistent economic growth is desirable so as to achieve improved construction industry contribution to GDP.
\end{abstract}

Keywords : Response, Nigeria, Construction Industry, Economic Growth

\section{INTRODUCTION}

The construction industry in Nigeria is one of the biggest employers of labour in the country. Despite the computer era we are now, the industry is still one of the few that relies a great deal on the individual skill and unskilled of workmen. Presently, there is, and always will be, the need for tradesmen such as: Bricklayers, Carpenters/Joiners, Plumbers, Electricians, Tilers among others.

The construction industry is often seen as a driver of economic growth especially in developing countries $[1] ;[2]$. Also in the United States, the industry (including design, new and renovation construction, and the manufacture and supply of building materials and equipment) is one of the largest industries [3]. [4], found a positive correlation between several measures of construction output and the level of income per capita. [5], stated that construction and the national output grow at the same rate only in a declining economy and that in a growing economy, the volume of construction typically, would not grow faster than the rest of the economy. Also, [1] affirmed that construction activities and its output are integral part of a country's national economy and industrial development. 
The construction industry contributes to the nation's gross national product and creates employment for the citizenry. According to [6], building construction sector is one of the top five sectors used in measuring the National Gross Capital Formation (NGCF) and the gross domestic product (GDP) of any country and its effect on every other sector makes it a significant front for sustainable development.

The industry is the world's largest industrial employer and in most countries it accounts for more than half of capital investment and as much as ten percent of GDP [7]. [8], stated that construction industry has potential for positive impact on economic growth and it is an important component in the investment programmes in developing economics. Also, [9], noted that construction through its extensive forward and backward linkages with other sectors of the economy generates one of the highest multiplier effects in terms of social development. [10]; [11]; [12], investigated the contribution of construction sector to Nigerian economy and opined that the industry was characterized with low contribution to GDP, in spite of the growth rate between 2006 and 2007, the contribution of construction to GDP remains very low at $1.88 \%$ in 2008 . However, construction has been adjudged to be one of the drivers of social and economic development of any nation [13]. The study conducted by [14], revealed the relationship between the construction sector and the national economy, that the evolution pattern of the share of construction Value Added (CVA) in GDP in the developing countries of Sub-Saharan Africa is marked differently according to the country stage of economic development, determined by Gross National Income (GNI) per capita. The discovery underscores the need for conducting research on specific behaviour of construction industry of each country to enable appropriate policy formulation and suitable economic sector [15]. [16], investigated the linkages between the construction sector and other sectors of Nigeria economy and found that construction significantly leads many sectors. Virtually all economic sectors feedback into the construction sector, thereby mutual interdependence of construction with other sectors of the economy was established. [17], also examined the effect of fiscal policy on sectoral output growth in Nigeria. A clear disparity in the sectoral response to fiscal policy was observed which underscored the inefficacy of conducting uniform and economy wide fiscal policy in Nigeria.

These few existing empirical studies have established some strength, weakness and opportunity for the Nigeria construction industry. The more empirical studies conducted to unravel the macroeconomics behaviours of the industry, the more the potential for discovering strategies for improving the productivity of the industry for improved contribution to national economy. Therefore, this study aims at assessing the response of Nigerian Construction industry to the economic growth of Nigeria, with a view to determining the impact of the industry on Nigeria economy, In achieving this, the specific objectives are to evaluate: the impact propensity, finite distributed lag and long run propensity of construction industry on the general economic growth of Nigeria. As at the time of this study, the sizes of Nigerian construction industry were small, medium and large.

\section{METHODS AND MATERIAL}

The construction industry is often seen as a driver of economic growth especially in developing countries [1]; [2]. Also in the United States, the industry (including design, new and renovation construction, and the manufacture and supply of building materials and equipment) is one of the largest industries [3]. [4], found a positive correlation between several measures of construction output and the level of income per capita. [5], stated that construction and the national output grow at the same rate only in a declining 
economy and that in a growing economy, the volume of construction typically, would not grow faster than the rest of the economy. Also, [1] affirmed that construction activities and its output are integral part of a country's national economy and industrial development.

The construction industry contributes to the nation's gross national product and creates employment for the citizenry. According to [6], building construction sector is one of the top five sectors used in measuring the National Gross Capital Formation (NGCF) and the gross domestic product (GDP) of any country and its effect on every other sector makes it a significant front for sustainable development.

The industry is the world's largest industrial employer and in most countries it accounts for more than half of capital investment and as much as ten percent of GDP [7]. [8], stated that construction industry has potential for positive impact on economic growth and it is an important component in the investment programmes in developing economics. Also, [9], noted that construction through its extensive forward and backward linkages with other sectors of the economy generates one of the highest multiplier effects in terms of social development. [10]; [11]; [12], investigated the contribution of construction sector to Nigerian economy and opined that the industry was characterized with low contribution to GDP, in spite of the growth rate between 2006 and 2007, the contribution of construction to GDP remains very low at $1.88 \%$ in 2008 . However, construction has been adjudged to be one of the drivers of social and economic development of any nation [13]. The study conducted by [14], revealed the relationship between the construction sector and the national economy, that the evolution pattern of the share of construction Value Added (CVA) in GDP in the developing countries of Sub-Saharan Africa is marked differently according to the country stage of economic development, determined by Gross National Income
(GNI) per capita. The discovery underscores the need for conducting research on specific behaviour of construction industry of each country to enable appropriate policy formulation and suitable economic sector [15]. [16], investigated the linkages between the construction sector and other sectors of Nigeria economy and found that construction significantly leads many sectors. Virtually all economic sectors feedback into the construction sector, thereby mutual interdependence of construction with other sectors of the economy was established. [17], also examined the effect of fiscal policy on sectoral output growth in Nigeria. A clear disparity in the sectoral response to fiscal policy was observed which underscored the inefficacy of conducting uniform and economy wide fiscal policy in Nigeria.

These few existing empirical studies have established some strength, weakness and opportunity for the Nigeria construction industry. The more empirical studies conducted to unravel the macroeconomics behaviours of the industry, the more the potential for discovering strategies for improving the productivity of the industry for improved contribution to national economy. Therefore, this study aims at assessing the response of Nigerian Construction industry to the economic growth of Nigeria, with a view to determining the impact of the industry on Nigeria economy. In achieving this, the specific objectives are to evaluate: the impact propensity, finite distributed lag and long run propensity of construction industry on the general economic growth of Nigeria. As at the time of this study, the sizes of Nigerian construction industry were small, medium and large.

\section{RESULTS AND DISCUSSION}

Table 1 shows the longitudinal data of Nigerian construction industry's output and growth together with that of Gross Domestic Product (GDP) and GDP growth over a 3 year time lag from 1981 to 2018. 
TABLE I. CONSTRUCTION GROWTH AND NIGERIA ECONOMIC GROWTH AT 2010 CONSTANT-PRICE 1981 - 2018 IN BILLIONS OF NAIRA

\begin{tabular}{|c|c|c|c|c|c|c|c|c|}
\hline $\mathrm{S} / \mathrm{N}$ & Year $(t)$ & $\begin{array}{c}\text { Const } \\
\text { Output (t) }\end{array}$ & $\begin{array}{c}\text { Econ } \\
\text { Output (t) }\end{array}$ & $\begin{array}{c}\text { CONSTG (t) } \\
(\%)\end{array}$ & $\begin{array}{c}\text { ECONG (t) } \\
(\%)\end{array}$ & $\begin{array}{c}\text { EconG } \\
(t-1) \\
(\%)\end{array}$ & $\begin{array}{c}\text { EconG } \\
(t-2) \\
(\%)\end{array}$ & $\begin{array}{c}\text { EconG } \\
(t-3) \\
(\%)\end{array}$ \\
\hline 1. & 1981 & 852.00 & 15258.00 & 0.00 & 0.00 & 0.00 & 0.00 & 0.00 \\
\hline 2. & 1982 & 679.00 & 14985.00 & -20.31 & -1.79 & 0.00 & 0.00 & 0.00 \\
\hline 3. & 1983 & 599.00 & 13850.00 & -11.78 & -7.57 & -1.79 & 0.00 & 0.00 \\
\hline 4. & 1984 & 488.00 & 13779.00 & -18.53 & -0.51 & -7.57 & -1.79 & 0.00 \\
\hline 5. & 1985 & 336.00 & 14954.00 & -31.15 & 8.53 & -0.51 & -7.57 & -1.79 \\
\hline 6. & 1986 & 336.00 & 15238.00 & 0.00 & 1.90 & 8.53 & -0.51 & -7.57 \\
\hline 7. & 1987 & 367.00 & 15264.00 & 9.23 & 0.17 & 1.90 & 8.53 & -0.51 \\
\hline 8. & 1988 & 404.00 & 16215.00 & 10.08 & 6.23 & 0.17 & 1.90 & 8.53 \\
\hline 9. & 1989 & 421.00 & 17295.00 & 4.21 & 6.66 & 6.23 & 0.17 & 1.90 \\
\hline 10. & 1990 & 442.00 & 19306.00 & 4.99 & 11.63 & 6.66 & 6.23 & 0.17 \\
\hline 11. & 1991 & 460.00 & 19199.00 & 9.00 & -0.55 & 11.63 & 6.66 & 6.23 \\
\hline 12. & 1992 & 478.00 & 19620.00 & 3.91 & 2.19 & -0.55 & 11.63 & 6.66 \\
\hline 13. & 1993 & 502.00 & 19928.00 & 5.02 & 1.57 & 2.19 & -0.55 & 11.63 \\
\hline 14. & 1994 & 517.00 & 19979.00 & 2.99 & 0.26 & 1.57 & 2.19 & -0.55 \\
\hline 15. & 1995 & 531.00 & 20353.00 & 2.71 & 1.87 & 0.26 & 1.57 & 2.19 \\
\hline 16. & 1996 & 537.00 & 21178.00 & 1.13 & 4.05 & 1.87 & 0.26 & 1.57 \\
\hline 17. & 1997 & 572.00 & 21789.00 & 6.52 & 2.89 & 4.05 & 1.87 & 0.26 \\
\hline 18. & 1998 & 606.00 & 22333.00 & 5.94 & 2.50 & 2.89 & 4.05 & 1.87 \\
\hline 19. & 1999 & 629.00 & 22449.00 & 3.80 & 0.52 & 2.50 & 2.89 & 4.05 \\
\hline 20. & 2000 & 654.00 & 23688.00 & 3.97 & 5.52 & 0.52 & 2.50 & 2.89 \\
\hline 21. & 2001 & 733.00 & 25268.00 & 12.08 & 6.67 & 5.52 & 0.52 & 2.50 \\
\hline 22. & 2002 & 764.00 & 28958.00 & 4.23 & 14.60 & 6.67 & 5.52 & 0.52 \\
\hline 23. & 2003 & 831.00 & 31709.00 & 8.77 & 9.50 & 14.60 & 6.67 & 5.52 \\
\hline 24. & 2004 & 775.00 & 35021.00 & -6.74 & 10.44 & 9.50 & 14.60 & 6.67 \\
\hline 25. & 2005 & 869.00 & 37475.00 & 12.13 & 7.01 & 10.44 & 9.50 & 14.60 \\
\hline 26. & 2006 & 981.00 & 39996.00 & 12.89 & 6.73 & 7.01 & 10.44 & 9.50 \\
\hline 27. & 2007 & 1109.00 & 42922.00 & 13.05 & 7.32 & 6.73 & 7.01 & 10.44 \\
\hline 28. & 2008 & 1254.00 & 46013.00 & 13.07 & 7.20 & 7.32 & 6.73 & 7.01 \\
\hline 29. & 2009 & 1404.00 & 49856.00 & 11.96 & 8.35 & 7.20 & 7.32 & 6.73 \\
\hline 30. & 2010 & 1571.00 & 54612.00 & 11.89 & 9.45 & 8.35 & 7.20 & 7.32 \\
\hline 31. & 2011 & 1818.00 & 57511.00 & 15.72 & 5.31 & 9.45 & 8.35 & 7.20 \\
\hline 32. & 2012 & 1989.00 & 59930.00 & 9.41 & 4.21 & 5.31 & 9.45 & 8.35 \\
\hline 33. & 2013 & 2272.00 & 63219.00 & 14.23 & 5.49 & 4.21 & 5.31 & 9.45 \\
\hline 34. & 2014 & 2568.00 & 67153.00 & 13.03 & 6.22 & 5.49 & 4.21 & 5.31 \\
\hline 35. & 2015 & 2680.00 & 69024.00 & 4.36 & 2.79 & 6.22 & 5.49 & 4.21 \\
\hline 36. & 2016 & 2521.00 & 67931.00 & -5.93 & -1.58 & 2.79 & 6.22 & 5.49 \\
\hline 37. & 2017 & 2546.00 & 68491.00 & 0.99 & 0.82 & -1.58 & 2.79 & 6.22 \\
\hline 38. & 2018 & 2605.00 & 69810.00 & 2.32 & 1.46 & 0.82 & -1.58 & 2.79 \\
\hline
\end{tabular}


Source: Central Bank of Nigeria

Table 2 shows the details of the time series regression (Model A) of construction growth at time $(t)$ on economic growth at four different time periods; time (t) for contemporaneous relationship with the construction growth. At time (t-1), (t-2) and (t-3) for one year lag, two year lag and three year lag respectively. The results showed that the maximum correlation exists between construction growth and economic growth at a year time lag (t-1) with regression coefficient of 0.843 and standardize coefficient of 0.367 to present the only significant independent variable at significance of 0.043. Impact propensity of construction growth on economic growth at time $(t)$ is weak with regression coefficient of -0.012 and standardize coefficient of -0.005 which is equally significant with significance of 0.970 .

TABLE III

A THREE YEAR LAG REGRESSION MODEL (A)

\begin{tabular}{|l|l|l|l|l|l|l|l|}
\hline & \multicolumn{2}{|c|}{ Unstandardized Coefficient } & \multicolumn{2}{c|}{ Standardize Coefficient } & \multicolumn{2}{c|}{ Collinearity Test } \\
\hline \multicolumn{1}{|c|}{ Variables } & Coefficient & \multicolumn{1}{|c|}{ Stand error } & Coefficient & T-test & Si.g & Tolerance & VIF \\
\hline Constant & -4.379 & 2.052 & - & -2.134 & 0.040 & - & - \\
\hline Econ G $(\mathrm{t})$ & -0.012 & 0.355 & -0.005 & -0.035 & 0.970 & 0.683 & 1.463 \\
\hline Econ G $(t-1)$ & 0.843 & 0.401 & 0.367 & 2.105 & .0 .43 & 0.528 & 0.892 \\
\hline Econ G $(t-2)$ & 0.398 & 0.400 & 0.174 & 0.993 & 0.328 & 0.524 & 1.907 \\
\hline Econ G $(t-3)$ & 0.721 & 0.356 & 0.312 & 2.021 & 0.051 & 0.676 & 1.479 \\
\hline
\end{tabular}

Table 3 shows the regression analysis of the alternative model B with construction growth at time $(\mathrm{t})$ on economic growth at time $(\mathrm{t})$ and $(t-1)$ thus dropping the two insignificant variables of $(t-2)$ and $(t-3)$. The results showed that contemporaneous effect of economic growth at time $(t)$ is with regression coefficient of 0.068 and insignificant while economic growth at $(t-1)$ is still the significant variable with improved coefficient of 1.265 and significance of 0.002 . Though, collinearity is high as expected from time series regression it is still within tolerable limit.

TABLE IIIII

A YEAR LAG REGRESSION MODEL (B)

\begin{tabular}{|l|l|l|l|l|l|l|l|}
\hline & \multicolumn{2}{|c|}{$\begin{array}{c}\text { Unstandardized } \\
\text { Coefficient }\end{array}$} & \multicolumn{2}{c|}{ Standardize Coefficient } & \multicolumn{2}{c|}{ Collinearity Test } \\
\hline Variables & Coefficient & Stand Error & $\begin{array}{c}\text { Coefficien } \\
\mathrm{t}\end{array}$ & T-test & Sig & Tolerance & VIF \\
\hline Constant & -1.838 & 2.052 & - & -0.895 & 0.377 & - & - \\
\hline Econ G (t) & 0.068 & 0.388 & 0.030 & 0.176 & 0.861 & 0.689 & 1.452 \\
\hline Econ G $(t-1)$ & 1.265 & 0.385 & 0.551 & 3.286 & 0.002 & 0.689 & 1.452 \\
\hline
\end{tabular}

Table 4 shows the general assessment of the two regression models A and B. Model A's statistic shows a better predictive power with regression coefficient of 0.685 , R-Square of 0.469 and standard error of 7.845 compared with model $B$ with regression coefficient of $0.568, \mathrm{R}$-Square of 0.323 and standard 
error of 8.604. However the regressive power of model B is superior with a better result on practical and statistical significance of the relationship between construction growth and economic growth with regression coefficient of 1.265 and significance of 0.002 . Therefore model $\mathrm{B}$ is the preferred regression model.

Based on model B, Finite Distributed lag of a two years cycle was accepted at (t) and ( $t-1)$ with regression coefficient $\delta_{0}$ and $\delta_{1}$ of 0.068 and 1.265 respectively. Long Run Propensity which is the sum of these finite distributed lag coefficients gives 1.333.

TABLE IVV

REGRESSION MODELS SUMMARY

\begin{tabular}{|c|l|c|c|}
\hline S/N & \multicolumn{1}{|c|}{ Parameters } & Model A & Model B \\
\hline 1. & R & 0.685 & 0.568 \\
\hline 2. & R-Square & 0.469 & 0.323 \\
\hline 3. & $\begin{array}{l}\text { Adjusted R- } \\
\text { Square }\end{array}$ & 0.405 & 0.284 \\
\hline 4. & Standard Error & 7.845 & 8.604 \\
\hline 5. & F-Statistics & 7.290 & 8.333 \\
\hline 6. & Significances & 0.000 & 0.001 \\
\hline
\end{tabular}

\section{IV.CONCLUSION}

The impact propensity of economic growth on Nigeria construction growth is weak and as a result, current year economic growth has insignificant influence on construction output in the current year. This has established the fact that Nigerian construction industry lags behind the general economy which has put paid to the inability of the industry to drive the economy from recession.

However, with the long run propensity of 1.333 which is the coefficient of one percent permanent growth in economy on construction, the industry has demonstrated a potential for high marginal growth rate, with the implication of an improving contribution as the economy grows. Therefore with consistent growth in economy, construction industry's contribution to the GDP would be increasing and could surpass most sectors presently leading construction in terms of contribution to GDP. A delayed effect of economic growth on construction output with a maximum impact felt a year after also reinforces the fact that construction industry is led by the general economic output. This makes the management decision making in the industry more effective with high confidence level in management decision making.

\section{REFERENCES}

[1] R. A. Khan. 2005. Role of Construction Sector in Economic Growth: Empirical Evidence from Pakistan economy. First International Conference on Construction in Developing Countries (ICCIDC-I). Proceeding paper in Advanced and Integrating Construction Education Research and Practice', August 4th5th, 2005 Karachi, Pakistan. Accessed: January 21st 2020, Available: www.researchgate.net $>$ publication $>28300778$ 1_Role_0...

[2] T. O. Oladiran, D. R. Ogunsemi, and Aje, I. O. 2012. Role of Construction Sector in Economic Growth: Empirical Evidence from Nigeria. FUTY Journal of the Environment. 7(1). pp. 5060.

[3] S. W. Nunnally. 2011. Construction Methods and Management. 8th Ed. Delhi Pearson Education International. P. 1.

[4] J. Wells. 1985. The Role of Construction in Economic Growth and Development. Habitat International. 9(1). pp. 55-70.

[5] J. Lopes. 1998). The Construction Industry and Macro-economy in Sub-Saharan African Post 1970. Construction Management and Economics. 16(6). pp. 637-649. 
[6] T. O. Mosaku, J. O. Kehinde and Kuroshi P. A. 2006). Control of Building Practices for Sustainable Development in Nigeria: Matters Arising. Proceedings of the International Conference on the Built Environment, Innovation, Policy and Sustainable Development, Department of Architecture, Covenant University, Ota, Nigeria, 24th - 26th January,2006.

[7] C. Du Plessis. 2001. Agenda 21 for sustainable construction in developing countries, A Discussion Document. Report for the GB and IWEP-IETC, CSIR Building Construction and Technology, Pretoria, 2001.

[8] S. Dlamini. 2012. Relationship of Construction Sector to Economic Growth, International Congress on Construction Management, Canada 2012.

[9] Osei. 2013. The Construction Industry and its linkages to the Ghanaian Economy- Policies to Improve the Sector's performance. International Journal of Development and Economic Sustainability. 1 (1). pp. 56-72.

[10] S. O. Anyanwu, U. S. Offor, O. M. Adesope, U. C. Ibekwe. 2008. Structure and Growth of Gross Domestic Product (1960-2005): Implication for Small Scale Enterprises in Nigeria, Global Advanced Research Journal of Management and Business Studies. 2(6). pp. 242-348.

[11] R. B. Isa, R. A. Jimoh, and E. Achuewu. 2013. An Overview of the contribution of construction sector to sustainable development in Nigeria, Net Journal of Business Management. 1(1). pp. 1- 6.

[12] National Industrial Revolution Plan (NIRP). 2014. National Industrial Revolution Plan Release 1.

[13] C. Rhodes. 2013. Construction Industry. Standard Note SN/EP/1432, Economic And Statistics, House Of Commons Library, London: HMSO.
[14] J. P. Lopes, R. A. Oliveire and M. I., Abreu. 2011. The Construction Industry and the Challenges of the Millennium Development Goals, Management and Innovation for a Sustainable built environment 20th - 23rd June, 2011, Amsterdam, The Netherlands.

[15] D. A. Dickey, W. A. and Futher. 2007. Distribution of the Estimators for Autoregressive time series with a unit root. Journal of the American Statistical Association. 74. pp. 427-431.

[16] N. Saka and J. Lowe. 2010. An assessment of linkages between the construction sector and other sectors of the Nigerian economy, The construction, Building and real Estate Research Conference of the Royal Institution of Chartered Surveyor 2nd - 3rd September, 2010, Dauphine University, Paris.

[17] O. H. Osinowo. 2015. Effect of Fiscal Policy and Sectoral Output Growth in Nigeria. Advances in Economics and Business. 3(6). pp. 195 - 203.

[18] Central Bank of Nigeria Statistics Database: statistics.cbn.gov.ng. Accessed: January 21st, 2020.

[19] J. M. Wooldridge. 2009. Introductory Econometrics: A Modern Approach (4th Edition), Canada: South-Western Cengage Learning.

\section{Cite this article as :}

Ojo O. J., Yusuf B. A., Anjonrin-Ohu A., "Response of Nigerian Construction Industry to Economic Growth", International Journal of Scientific Research in Science and Technology (IJSRST), Online ISSN : 2395-602X, Print ISSN : 2395-6011, Volume 7 Issue 2, pp. 506-512, March-April 2020. Available at doi : https://doi.org/10.32628/IJSRST207293 Journal URL : http://ijsrst.com/IJSRST207293 